\title{
Miten avoin julkaiseminen vaikuttaa kirjastojen tietoaineistoihin ja mikä on kirjaston rooli aineistojen jakajana?
}

\author{
Kristiina Lähdesmäki
}

\begin{abstract}
Suomen tieteellisen kirjastoseuran huhtikuisessa seminaarissa Tietoresurssit ja avoimet aineistot esiteltiin jo toteutuneita ja valmisteilla olevia hankkeita avoimen tieteen ja aineistojen tiimoilta. Avoimen materiaalin etsiminen ja löytäminen myös kiinnosti seminaariyleisöä.
\end{abstract}

\section{Avoimet julkaisualustat}

Avoimia julkaisualustoja esittelivät sekä Sven Fund Knowledge Unlatched -palvelusta että Niklas Alén Suomalaisen Kirjallisuuden Seurasta (SKS).

Knowledge Unlatched (KU) julkaisualustalla on avoimia englanninkielisiä humanistisia ja yhteiskuntatieteellisiä monografioita. Palvelu sisältää yli 450 monografiaa yli 60 kustantajalta ja mukana maksavina osallistujina on yli 450 kirjastoa yli 26 maasta. Uutena palveluna tarjotaan Language Science Pressiä. Jatkossa KU:hun tulee sisältymään myös tieteellisiä lehtiä.

Suomalaisen Kirjallisuuden Seuran kirjastokonsortio Aleksandriassa on mukana seitsemän kirjastoa ja alustalla on nyt kymmenen avoimesti tarjolla olevaa suomenkielistä teosta. Teokset ovat CC-lisenssoituja ja niitä voi täten käyttää laajemmin opetuskäyttöön. Teoksia voi lukea ilman erillistä lukuohjelmaa ja ne löytyvät myös kirjastotietokannoista. Kirjamyynti ei vielä kata kaikkia julkaisemisen kuluja. Hinnoittelumallina toimivatkin Freemium- ja Premium-malli. Freemiummallissa versiot ovat maksuttomia, kun taas Premium-mallissa tutkijan kirjoittajamaksu kattaa avoimen julkaisemisen maksun. SKS on avaamassa monia tieteitä sisältävän Studia Fennica -sarjan englanninkieliset kirjat avoimesti verkkoon. Suomen historiallisen seuran historiallisia sarjoja ollaan digitoimassa. Myös Elias Lönnrotin kirjeenvaihto on digitoitu (http://lonnrot.finlit.fi).

Yleisöä kiinnosti, onko väärin käyttää hy- väkseen muiden vapaaksi maksamia aineistoja. Vastaukseksi saatiin: Mitä useampi osallistuu, sitä pienempi on yksittäinen maksuosuus ja että toisaalta pitä kannattaa hyvää asiaa.

\section{Vaihtoehtoisia polkuja artikkeleiden luo}

Paula Mikkonen FinELib:istä kertoi vaihtoehdoista sille, ettei aineistolisenssiä olisi solmittu. Tämä tarkoittaa tilanteita, joissa organisaatiolla ei ole varaa tilata laajaa aineistoa, aineistolla ei olisi tarpeeksi käyttöä, joudutaan tekemään valintoja aineistojen välillä, suunnataan varoja uusiin aineistoihin, kuten avoimeen julkaisemiseen tai aineistojen lisenssiehdoista ja hinnasta ei päästä sopimukseen.

Ratkaisuiksi em. tilanteisiin ehdotettiin seuraavia: Lisensioidun lehtipaketin pitkäaikaiskäyttö tarjoaa tilaajille pääsyn sopimuksesta riippuen tiettyjen vuosien lehtiin. Yksittäisiä lehtiartikkeleita voi ostaa kustantajien sivuilta. Rinnakkaistallennetut julkaisut ovat saatavilla. Tilausmaksullisissa lehdissä on avoimeksi ostettuja yksittäisiä artikkeleita. Saatavilla ovat myös artikkelit, jotka kustantaja avaa viiveellä avoimiksi sekä lisenssisopimuksiin sisältyvät avoimet artikkelit. Tutkijat voivat jakaa toisilleen tieteellisen kommunikaation nimissä lisensioitujen elektronisten aineistojen artikkeleita tutkimustarkoituksiin, jos sopimus sen sallii. Artikkeleita voi myös tilata kaukopalvelun kautta. 


\section{Tutkijoiden luottamus kirjastoihin tiedonvälittäjänä vankka}

Tutkija Elina Late Tampereen yliopistosta kertoi vuoden 2016 tutkimuksesta "Tutkijat ja lukeminen - kirjastot ja kollegat tiedonlähteinä".

Tutkimuskysymyksenä oli mitä ja miksi tutkijat lukevat ja miten he löytävät erilaisia julkaisuja työssään. Tieteelliset artikkelit ovat edelleen tärkeimpiä tutkijan tiedonlähteitä. Kirjaston kautta saaduista artikkeleista $91 \%$ saatiin elektronisessa muodossa ja näistä $43 \%$ luettiin painettuina printteinä. Tutkimustyön tärkeimpinä tiedonlähteinä pidettiin nimenomaan kirjaston kautta saatuja artikkeleita ja kirjoja, joihin myös viitattiin eniten. Kollegoiden kautta saatuihin artikkeleihin ja kirjoihin viitattiin harvemmin. Kirjastojen rooli luotettavan tiedon välittäjänä saa vahvan tuen tutkijoilta.

Tieteellisissä julkaisuissa lukeminen kohdistuu usein vain tiettyyn osaan julkaisua, jota luetaan useampaan kertaan. Muita julkaisuja luetaan yleensä kertaalleen kokonaisuuksina.

\section{Onko avoimen tiedon löytyminen sattuman kauppaa?}

Leena Elenius Seinäjoen ammattikorkeakoulusta etsi vastausta kysymykseen, onko avoimen tiedon löytäminen sattuman kauppaa. Avoimelle aineistolle ei ole kehitetty pysyvää arkistointia ja siksi julkisten organisaatioiden kuten kaupunkien, kuntien ja tutkimuslaitosten tuottama ei-virallinen aineisto häviää kun verkkosivut uusitaan. Internet Archive voisi olla tässä apuna aineistojen haussa. Avointa tietoa tulisi kuvailla omaan kokoelmaan kirjaston omien hakuindeksien ulottuville. Julkaisuarkistot ovat toimivia avoimen tiedon säilytyspaikkoja. Oman alan tiedontuottajat ja tiedontuotannon perinteet on hyvä tuntea ja seurata asiantuntijoita sosiaalisessa mediassa.

\section{Alkaneita ja päättyneitä hankkeita}

Marjo Kuusela kertoi Helsingin yliopiston kirjaston Avoimen julkaisemisen (OA) palvelukeskushankkeesta vuosille 2017-2019.

Tavoitteena on julkaisualustan hankinta ja käyttöönotto eli Helsinki University Pressin avoimen OA-ssarjan perustaminen yhteistyössä Gaudeamuksen kanssa. Projektin aikana luodaan käytänteet kirjoittajamaksujen hallinnointiin sekä kootaan yhteen kirjaston nykyiset avoimeen julkaisemiseen liittyvät eri toiminnot. Lisätietoja löytyy tutkijan Open Access -oppaassa (http:// libraryguides.helsinki.fi/oa).

Juuri avattua ulkomaisten verkkojulkaisujen LUMI-hakupalvelua esittelivät Hannele Pakarinen ja Lena Lönngren Tieteellisten seurain valtuuskunnasta. LUMI-hakupalvelu (Lista UlkoMaisista Internetjulkaisuista) on Tieteellisen kirjallisuuden vaihtokeskuksen tuottama ulkomaisten verkkojulkaisujen hakupalvelu. Tietokantaan on kerätty tietoja vaihtona saapuvien painettujen julkaisujen rinnakkaisista verkkoversioista. Listaa kartutetaan ja päivitetään jatkuvasti julkaisuvaihtotoiminnan yhteydessä sekä käyttäjäpalautteen perusteella. Mukana on noin 1000 pääasiassa tieteellistä verkkojulkaisua eri tieteenaloilta. Suurin osa näistä on avoimesti saatavilla, mutta mukana on myös hybridilehtiä eli tilausmaksullisia julkaisuja, joissa vain osa artikkeleista on avoimesti luettavissa. LUMI-hakupalveluun on välittömästi avoimien julkaisujen lisäksi hyväksytty myös viiveen jälkeen avoimet julkaisut. LUMI löytyy osoitteesta: https://www.tsv.fi/vaihtokeskus/kirjastot/e-index.php

\section{Tietoa kirjoittajasta:}

Kristiina Lähdesmäki

Helsingin yliopiston kirjasto

kristiina.lahdesmaki@helsinki.fi 